\title{
Re-viewing Portfolio Writing from a Metacognitive Perspective
}

\author{
Devika A \\ Researcher Scholar \\ Bharathiar University \\ Coimbatore, Tamil Nadu, India \\ devika.rdh@gmail.com
}

\begin{abstract}
Portfolio writing, a pedagogic construct of the late $20^{\text {th }}$ century, which can be viewed as one of the latest branchings of the mainstream writing research, can also be considered as an offshoot of the 'paradigm shift' (Thomas Kuhn,1962) from the long prevailing product approach to an emerging process approach. Theory, research and classroom practice, all had been confined to the written products; and 'the writer' was more or less neglected. The process approach brought to the forefront, the psyche of the writer by giving equal importance to the psychocognitive processes underlying the activity. The term 'activity' has been used here in the sense that writing is a higher order mental activity. Portfolio writing, moving one step further, reveals not only the writer's ability at composing in the present, but consolidates the schema of the past, as well as forecasts the writing potentials of future, too. This paper tries to validate, how simultaneously the process and the product together result in the learning outcome, in the context of assessing writing performance.
\end{abstract}

Writing in a second language share the complexities of both writing as tutored activity as opposed to speaking as a natural gift and learning a second language in an artificial set up as opposed to acquiring (Krashen,2003) the first language with the help of the innate language 
mechanism (Chomsky ,2004). Thus, it remains 'twice removed from reality', hence the hurdles in teaching and barriers in learning. In the case of the first language, when 'skill getting' and 'skill using' (Rivers,1983) take place almost simultaneously, in the case of an enforced second language learning situation, the latter stage has to wait till the former gets rather matured. An incubation period seems to be inevitable. Speech sounds are mastered not in isolation in the first language - in fact, the learner is not at all aware of the presence of, and the role played by speech sounds; they are constituents of meaning signifying units: ds or phrases. But, in writing, letters come first; they carry no meaning. These are some of the basic barriers which distance the second language learner from writing.

The other side of the picture adds to the dilemma of the teacher. In a second language as English in India, life is more or less embedded in the second language, as far as the twenty first generation learners are concerned. Writing is the primary basis upon which one's academic output, intellectual caliber and above all, one's career prospects are judged. How to bridge this gap will always remain a challenge in SL writing instruction.

Writing equips learners with communication and thinking skills. Writing fosters the ability to explain and refine ideas to others and ourselves. It also gives voice to our inner thoughts and allows us to share them. Good writing skills allow communicating of the message with clarity and ease to a larger audience than through face to face or telephonic conversations. It is one of the tiring experiences for students in school, but it is also one of the essentials. Beyond academic purposes, business, digital age, e-mails, online conversations, faxes, website updates all these require excellent writing skills. The clearer the communication is, the greater will be the chance of high success rate. Moreover, writing also facilitates a person to think better. When a student learns to write, he/she becomes more capable of analyzing what he/she reads, interprets and thinks. 
Here comes the significance of student portfolio writing. Paulson et al. (1991) state that a portfolio is purposeful collection of student work that exhibits the student's efforts, progress and achievements in one or more areas of the curriculum. Portfolios should represent a collection of student's best work or best efforts, student - selected samples of work experiences related to outcomes being assessed and documents recording growth and development toward mastering identified outcomes. Portfolio writing is a limited collection of a student's writing which is different from traditional writing folder. A portfolio contains the best efforts of students the teachers can allow students to write for different purposes and audiences and in different forms. Creating a stimulating environment will help students to immerse themselves in writing. Portfolios can transform beginning writers to practicing writers who regularly compose thinking, talking and exploring options in their writing over and over again. The students should be given enough freedom to choose the topics for student portfolios. For example, items such as,

- Slogans based on topics of current relevance (as many as possible)

- Conversation between a teacher and a student (based on any situation)

- Imperatives (commands or requests) usually you hear from school or home. (as many as possible)

- $\quad$ Shopping list.

- Notice board which you see in public places like bus stop, hospitals, railway stations, Government offices etc... (eg.- 'No SMOKING')

- Common expressions used for asking permission. (eg: - May I come in?)

- Small poems (6-8 lines) based on any topic of your interest.

- Diary entry (concentrating on any context)

- Study time - table to be followed at home.

- Translations of newspaper headlines from mother tongue to English 
- Travel diary (based on any trip which you had enjoyed)

- How do you enjoy your school life?

- A paragraph about child labour, as a social issue.

- "Home, Sweet Home". Write a paragraph about the love, care and protection that you get from your parents.

- Curriculum vita

- Poem about nature

- Cinquains

- Memorable day in my life

- First day in the school

- Classroom experience

- Greetings

- Conversation

All these activities must be done only through the thinking process of the students. Hence metacognition is of great significance.

The process portfolio documents all facets or phases of the learning process. It is particularly useful in documenting students' overall learning process. It can show how students integrate specific knowledge or skills and progress towards both basic and advanced mastery. Additionally, the process portfolio inevitably emphasizes students' reflection upon their learning process, including the use of reflective journals, think logs, and related forms of cognitive processing.

Developing portfolio requires a good understanding of the performance standards by which the student will be judged and careful selection of artifacts that best illustrate growth and development attained as a result of gaining mastery of various instructional objectives. The students can collect both their worst and best products to show gains and improvements. 
Reflection is the act of looking back in order to process experiences. Metacognition, a type of reflection, is a way of thinking about one's thinking in order to grow. Most often metacognition and reflection are terms used interchangeably. But it will be better to consider metacognition as a particular form of reflection. Reflection is not a static form. Reflection can work in many dynamic ways such as talking, writing letters, formal essays etc. Teachers can give many activities in the classroom to practice reflection in a variety of ways. Thus, effective metacognition can be facilitated.

Flavell (1976) defined metacognition as knowledge about cognition and control of cognition. Metacognition is "cognition about cognition", 'thinking about thinking'. The term comes from the root word 'meta' meaning 'beyond' or 'on top of'. Creating communication is precise because words are chosen by the writer with great care. Hence it is a result of metacognition. Metacognition is put simply, thinking about one's thinking. Metacognition practices help students become aware of their strengths and weaknesses as learners, writers, readers etc. It includes a critical awareness of

a) One's thinking and learning

b) Oneself as a thinker and learner.

Meta cognition, or thinking about one's thinking is key to facilitating lasting learning experiences and developing lifelong learners. Linda Darling Hammond and her colleagues (2003) identify two types of metacognition: reflection or "thinking about what we know" and self-regulation, or "managing how we go about learning".

Metacognitive activities can guide students as they,

- $\quad$ identify what they already know

- $\quad$ communicate their language

- $\quad$ set goals and monitor their progress.

- $\quad$ revise their own work after evaluation 
- Transfer learning from one content to another

Activities that promote metacognition should:

- facilitate equal participation

- $\quad$ ensure student do most of the writing and speaking

- $\quad$ happen in different group configuration (individuals, pairs, small group, large group)

\section{Activity 1: Translation from mother tongue to English}

Divide the class into 3 or 4 groups

Distribute newspapers daily among the group. Ask the students to translate the newspaper headlines from their mother tongue to English.

\section{Activity 2: Preparation of Script}

Students can be asked to prepare a script of a role play selecting any topic of their own interest.

\section{Activity 3: Preparation of Notice Boards}

The students can be asked to think about the notice boards which they see in different places in their real-life situations. This can be given as an individual work.

\section{Activity 4: Preparation of Travel Diary}

Ask the students to write a travel diary about a trip they have made recently. (Individual/pair work)

Conclusion

In short, if the teacher wants to foster creativity in schools, it is very much essential that the creative thought process of the students must be given due consideration. It is also very significant that the students' awareness about what their creative thinking is. Metacognition is vital component of the creative cognition when it is related with the thought process. It will help them to create new meaning which will indeed lead to innovative ideas. Hence it is 
necessary to develop metacognitive skills to support students to understand what and how they are learning together for their development. The ultimate way of promoting student success is by incorporating their metacognitive and scientific literate skills in one. 


\section{References}

Elbow, P., and Belanoff, P, (1991). 'Portfolios as a substitute for Proficiency Examinations'. College Composition and Communication, 37, 336-39.

George, B. (1995). 'The student teaching Portfolio’ Research article, sage journals.

Hariston, M. (1982). 'The Wings of Change: Thomas Kuhn and the Revolution in Teaching writing. 'College Composition and communication 33 (1): 76-88.

Hillocks, G. (1995). 'Teaching writing as reflective practice'. New York. Teachers College Press.

Paulson, F.L., Paulson, P.R., and Meyer, C.A. (1991). 'What Makes a Portfolio a Portfolio?' Educational Leadership. 48(5), 60-63.

Raimes, A. (1983) 'Techniques in Teaching Writing'. Oxford: Oxford University Press: print p. 6.

Thornton, G. (1980). 'Teaching writing: The Development of written Language Skills'. London: Edward Arnold.

https://www.critical thinking.org. Paul

https://www.learning theories.com. 